\title{
Overview of the Issue
}

\author{
JEFFREY BROWN, STEVEN HABERMAN, MOSHE MILEVSKY \\ and MIKE ORSZAG
}

Since the inception of the Journal, it has been published in conjunction with the International Network of Pension Regulators and Supervisors (INPRS), a network setup and administered by the OECD. Because of the importance of pension supervision, it has become clear that a network such as the INPRS is not enough and as a result a new international organization, International Organisation of Pension Supervisors (IOPS), has been formed and will deal with issues relating to pensions supervision. The OECD will provide secretariat services for IOPS as it did for INPRS. Going forward, we are grateful to have the support from IOPS to be publishing the Journal in association with them. The OECD's private pension working party will handle more policy-related issues and we are also grateful to have the support from this group. Going forward therefore the Journal will be published in association with IOPS and the OECD.

This issue features three original research articles, one issues \& policy articles and a book review section. The first article "The Rate of Return of Pay-As-You-Go Pension Systems - A More Exact Consumption-Loan Model of Interest" is by Ole Settergren and Boguslaw D. Mikula and revisits the classical contribution of (Paul Samuelson, 1958) on the rate of return of a pay as you go pension system. Settergen and Mikula show analytically that the result of (Paul Samuelson, 1958) and (Henry Aaron, 1966) changes when there are more than two periods. The difference in returns is the change in "expected turnover duration" or how the age and income distribution of contributors and beneficiaries evolves. Settergren and Mikula illustrate their model (which is in active use in the Swedish notional defined contribution system) with some numerical calculations for range of developing and developed countries.

In the second paper, Juha Alho, Svend Jensen, Jukka Lassila, and Tarmo Valkonen look at "Controlling the Effects of Demographic Risks: The Role of Pension Indexation Schemes". How to index pensions is currently an important topic in the policy debate in the United States and elsewhere and this paper casts light on this important problem by discussing and analysing a system in which benefits are indexed to total wage bills rather than average wages. Using an overlapping generations model, the authors show that this leads to less volatile contribution rates and more fluctuation in benefit rates. Yet at the same time, the authors find that these fluctuations in benefit rates are not too large.

The third article on "Social Security Personal-Account Participation with Government Matching" was contributed by Gary Engelhardt (Syracuse University) and Anil Kumar (Federal Reserve Bank of Dallas) empirically examines the effect 
of matching contributions on personal account participation of workers aged 40 to 65 in the United States. They find that participation is not very elastic to matching and that match rates are reasonably high. Engelhardt and Kumar suggest that under a specific parameterised policy over $70 \%$ of middle aged and older workers would participate in a match. Yet at the same time there are a lot of differences in who takes up matches, with those poorer and with lower levels of education less likely to participate, suggesting some distributional issues associated with reliance on matching contribution incentives.

The effects of migration on public pension costs are the focus of an issues \& policy piece by Sonja Munz (IFO, Germany) and Martin Werding (IFO and CESifo, Germany) entitled "Public Pensions and International Migration: Some Clarifications and Illustrative Results". Although increased migration is only likely to slightly reduce pension funding problems, Munz and Werding present calculations for Germany, Italy, the UK and US that at least for permanent migration, the effects of migration are to reduce costs, particularly if the migrants are in higher skill/wage brackets. For temporary migration, the cost-benefit balance is less clear, particularly for lower wage migrants to the UK and US, but in general migrants do bring economic benefits which as quantified by the authors are not insignificant measured on a per migrant basis. The authors point out though that the fact that countries are extracting such rents from migrants may in itself discourage migration.

The issue closes with a book review section (edited by Olivia Mitchell) with five new reviews of pensions-relevant books. The book reviews are contributed by: Zvi Bodie (Boston University), Ronald G. Albahary (SEI Investments), Emily Andrews (World Bank), Monika Bütler (CEPR) and Miki Arimori (Nikko Financial Intelligence).

For news about forthcoming articles and other content, we encourage you to take a look at the Journal website (http://www.pensions-journal.com). For online access to the Journal, please visit the Cambridge University Press Journals website; http://journals.cambridge.org.

\section{References}

Aaron, Henry (1966) The Social Insurance Paradox. Canadian Journal of Economics and Political Science, 32(3): 371-374.

Samuelson, Paul (1958) An Exact Consumption-Loan Model of Interest with or without the Social Contrivance of Money. Journal of Political Economy, 66(6): 467-482. 